E-JURNAL EKONOMI DAN BISNIS UNIVERSITAS UDAYANA
Available online at https://ojs.unud.ac.id/index.php/EEB/index
Vol. 10 No. 10, October 2021, pages: 839-848
e-ISSN: 2337-3067

\title{
DAMPAK BPNT TERHADAP KONSUMSI RUMAH TANGGA DAN POLA KONSUMSI RUMAH TANGGA PENERIMA BPNT, KECAMATAN MENGWI
}

\section{Luh Ade Yumita Handriani ${ }^{1}$ Sudarsana Arka ${ }^{2}$}

\begin{tabular}{l}
\hline \multicolumn{1}{c}{ Article history: } \\
\hline Submitted: 13 Mei 2021 \\
Revised: 8 Juni 2021 \\
Accepted: 13 Juni 2021 \\
\end{tabular}

Keywords:

Non-Cash Food Assistance Program;

Household Consumption;

Household Consumption Pattern;

\section{Kata Kunci:}

Program Bantuan Pangan Non Tunai:

Konsumsi Rumah Tangga;

Pola Konsumsi Rumah Tangga;

\section{Koresponding:}

Fakulas Ekonomi dan Bisnis Universitas Udayana, Bali, Indonesia

Email:

adeyumitaa@gmail.com
Abstract

This study aims to analyze the impact of the BPNT program on household consumption and consumption patterns of BPNT recipient households in Mengwi District, Badung Regency. This research was conducted in Mengwi District, Badung Regency using a questionnaire distributed to respondents with a large sample size of 96 KPM. This study uses path analysis techniques to analyze the direct effect and Sobel test to analyze the indirect effect. Based on path analysis, the results of the study concluded that the BPNT variable had a positive and significant effect on the consumption of BPNT recipient households in Mengwi District, Badung Regency. The BPNT variable has no effect on the consumption pattern of BPNT recipient households in Mengwi District, Badung Regency. The household consumption variable has a negative and significant effect on the consumption pattern of BPNT recipient households in Mengwi District, Badung Regency. The household consumption variable did mediate the effect of the BPNT Program on the consumption pattern of BPNT recipient households in Mengwi District, Badung Regency.

Abstrak
Penelitian ini bertujuan untuk menganalisis dampak program BPNT
terhadap konsumsi rumah tangga dan pola konsumsi rumah tangga penerima
BPNT di Kecamatan Mengwi Kabupaten Badung. Penelitian ini dilakukan
di Kecamatan Mengwi Kabupaten Badung menggunakan kuesioner yang
disebarkan kepada responden dengan ukuran sampel yaitu sebanyak 96
KPM. Penelitian ini menggunakan teknik analisis jalur/path untuk
menganalisis pengaruh langsung dan uji sobel untuk menganalisis pengaruh
tidak langsung. Berdasarkan analisis jalur, hasil penelitian memperoleh
kesimpulan bahwa variabel BPNT berpengaruh positif dan signifikan
terhadap konsumsi rumah tangga penerima BPNT di Kecamatan Mengwi
Kabupaten Badung. Variabel BPNT tidak berpengaruh terhadap pola
konsumsi rumah tangga penerima BPNT di Kecamatan Mengwi Kabupaten
Badung. Variabel konsumsi rumah tangga berpengaruh negatif dan
signifikan terhadap pola konsumsi rumah tangga penerima BPNT di
Kecamatan Mengwi Kabupaten Badung. Variabel konsumsi rumah tangga
memediasi pengaruh Program BPNT terhadap pola konsumsi rumah tangga
penerima BPNT di Kecamatan Mengwi Kabupaten Badung.

\section{Abstrak} terhadap konsumsi rumah tangga dan pola konsumsi rumah tangga penerima BPNT di Kecamatan Mengwi Kabupaten Badung. Penelitian ini dilakukan di Kecamatan Mengwi Kabupaten Badung menggunakan kuesioner yang disebarkan kepada responden dengan ukuran sampel yaitu sebanyak 96 KPM. Penelitian ini menggunakan teknik analisis jalur/path untuk menganalisis pengaruh langsung dan uji sobel untuk menganalisis pengaruh tidak langsung. Berdasarkan analisis jalur, hasil penelitian memperoleh kesimpulan bahwa variabel BPNT berpengaruh positif dan signifikan terhadap konsumsi rumah tangga penerima BPNT di Kecamatan Mengwi Kabupaten Badung. Variabel BPNT tidak berpengaruh terhadap pola konsumsi rumah tangga penerima BPNT di Kecamatan Mengwi Kabupaten Badung. Variabel konsumsi rumah tangga berpengaruh negatif dan signifikan terhadap pola konsumsi rumah tangga penerima BPNT di memediasi pengaruh Program BPNT terhadap pola konsumsi rumah tangga penerima BPNT di Kecamatan Mengwi Kabupaten Badung.

Fakultas Ekonomi dan Bisnis Universitas Udayana, Bali, Indonesia²

Email: sudarsanaarka@gmail.com 


\section{PENDAHULUAN}

Vincen (2009) mengemukakan bahwa kemiskinan merupakan masalah yang kompleks baik pada negara maju maupun negara berkembang, sehingga memerlukan strategi yang tepat dan berkelanjutan dalam mengatasinya. Kemiskinan terjadi karena dipengaruhi oleh beberapa faktor seperti kurangnya kesempatan kerja, upah yang tidak sebanding dengan pekerjaan yang dilakukan sehingga tidak dapat memenuhi kebutuhan, dan juga kualitas sumber daya manusia yang kurang karena kurangnya Pendidikan yang dapat ditempuh. Menurut Akhtar (2017), Pendidikan memiliki hubungan yang erat dengan kemiskinan karena orang tua tidak dapat membiayai Pendidikan anakanaknya.

Sukirno (2001) menyebutkan bahwa konsumsi dibiayai oleh banyak faktor selain pendapatan, seperti tabungan, penjualan harta kekayaan, dan pinjaman. Hal ini terjadi karena tingkat pengeluaran yang lebih tinggi dari pendapatan yang diterima, sehingga semakin tinggi pendapatan maka akan semakin tinggi pemenuhan konsumsi sehari-hari. Hal ini menunjukkan bahwa pendapatan memiliki hubungan dengan kemiskinan, dan juga akan berpengaruh terhadap kesejahteraan masyarakat serta kualitas sumber daya manusia. Melihat fenomena ini, pemerintah menyalurkan program-program yang berfokus pada kesejahteraan masyarakat kurang mampu atau yang tidak mampu memenuhi kebutuhan hidupnya.

Untuk meningkatkan efektivitas dan agar tepat sasaran dalam penyaluran bantuan sosial serta mendorong inklusi keuangan, Presiden Republik Indonesia memberikan arahan agar bantuan sosial dan subsidi disalurkan secara non tunai pada Rapat Terbatas (Ratas) tentang Keuangan Inklusif tanggal 26 April 2016. Penyaluran Beras Sejahtera (Rastra) ini kemudian dilakukan melalui kupon elektronik (e-voucher) untuk membeli beras serta bahan pangan bergizi, sesuai jumlah dan kualitas yang diinginkan. Dengan demikian, tujuan Program Bantuan Pangan secara non tunai adalah untuk meningkatkan ketepatan kelompok sasaran; memberikan gizi yang lebih seimbang; lebih banyak pilihan dan kendali kepada rakyat miskin; mendorong usaha eceran rakyat; memberikan akses jasa keuangan pada rakyat miskin; dan mengefektifkan anggaran. Dalam jangka panjang, penyaluran bantuan pangan secara non tunai diharapkan berdampak bagi peningkatan kesejahteraan dan kemampuan ekonomi penerima manfaat. Agar pelaksanaan program Bantuan Pangan berjalan baik dan dapat mencapai tujuannya, maka disusunlah Pedoman Umum Bantuan Pangan sebagai acuan teknis pelaksanaan di lapangan. Di Kecamatan Mengwi masih banyak masyarakat miskin yang memerlukan bantuan.

Keluarga Penerima Manfaat (KPM) yang menerima Bantuan Pangan Non Tunai (BPNT) cenderung mengalami peningkatan dari $2471 \mathrm{KPM}$ pada tahun 2018 menjadi $2523 \mathrm{KPM}$ pada tahun 2020. Dengan demikian adanya program BPNT ini diharapkan mampu membantu pengeluaran rumah tangga di Kecamatan Mengwi Kabupaten Badung. Tujuan program ini selain meningkatkan ketepatan kelompok sasaran, juga untuk memberikan nutrisi yang lebih seimbang, memberikan lebih banyak pilihan dan kendali kepada rakyat miskin, mendorong usaha eceran rakyat, serta memberikan akses jasa keuangan, dan mengefektifkan anggaran. Selain itu, penyaluran bantuan pangan secara non tunai juga diharapkan berdampak bagi peningkatan kesejahteraan dan kemampuan ekonomi penerima bantuan pangan non tunai.

BPNT merupakan bantuan sosial pangan dalam bentuk non tunai dari pemerintah yang diberikan kepada KPM setiap bulannya melalui mekanisme akun elektronik yang digunakan hanya untuk membeli bahan pangan di pedagang bahan pangan/e-warong Kelompok Usaha Bersama (KUBE) yang bekerjasama dengan bank HIMBARA (Choesni et al., 2017), yang bertujuan untuk mengurangi beban pengeluaran KPM dalam memenuhi sebagian kebutuhan pangannya, sehingga 
memiliki lebih banyak pilihan dalam memenuhi kebutuhan dan mendorong pencapaian tujuan pembangunan berkelanjutan (Kemensos, 2017).

Tabel 1.

Jumlah KPM Yang Mendapatkan Bantuan Pangan Non Tunai Tahun 2018-2020

\begin{tabular}{lccc}
\hline DESA KELURAHAN & $\begin{array}{c}\text { TAHUN } \\
\mathbf{2 0 1 8}\end{array}$ & TAHUN 2019 & $\begin{array}{c}\text { TAHUN } \\
\mathbf{2 0 2 0}\end{array}$ \\
\hline ABIANBASE & 66 & 63 & 63 \\
BAHA & 169 & 162 & 162 \\
BUDUK & 49 & 41 & 41 \\
CEMAGI & 0 & 36 & 36 \\
GULINGAN & 188 & 231 & 231 \\
KAPAL & 114 & 86 & 86 \\
KEKERAN & 212 & 215 & 215 \\
KUWUM & 36 & 56 & 56 \\
LUKLUK & 124 & 97 & 97 \\
MENWI & 135 & 133 & 133 \\
MENGWITANI & 192 & 148 & 148 \\
MUNGGU & 16 & 76 & 76 \\
PENARUNGAN & 163 & 188 & 188 \\
PERERENAN & 14 & 11 & 11 \\
SADING & 222 & 229 & 229 \\
SEMBUNG & 160 & 150 & 150 \\
SEMPIDI & 135 & 128 & 128 \\
SOBANGAN & 128 & 127 & 127 \\
TUMBAK BAYUH & 88 & 95 & 95 \\
WERDI BHUWANA & 260 & 251 & 251 \\
\hline
\end{tabular}

Sumber : BPS Bali, 2021

Sukirno (1994) menyatakan bahwa konsumsi rumah tangga adalah nilai belanja yang dilakukan oleh rumah tangga untuk membeli berbagai jenis kebutuhannya dalam satu tahun tertentu. Pendapatan yang diterima rumah tangga akan digunakan untuk membeli makanan, membiayai jasa angkutan, membayar pendidikan anak, membayar sewa rumah dan membeli kendaraan. Dumairy (1996) yang mengalokasikan konsumsi masyarakat kedalam dua kelompok penggunaan, yaitu: pengeluaran untuk makanan dan pengeluaran untuk bukan makanan. Pola konsumsi masyarakat berbeda antara satu dengan yang lain, bila semakin rendah pengeluaran masyarakat maka alokasi pengeluarannya akan semakin didominasi oleh konsumsi pangan, semakin tinggi pengeluaran, maka makin besar proporsi belanja untuk konsumsi bukan makanan. Menurut Hukum Engel, makin tinggi penghasilan suatu keluarga, makin besar jumlah uang yang dikeluarkan untuk kebutuhan primer, khususnya makanan. Hukum Engel ini juga menyatakan bahwa proporsi pengeluaran konsumsi untuk makanan dapat dijadikan ukuran standar hidup yang baik sehingga dapat mencerminkan tingkat kesejahteraan. Tapi secara relatif bagian yang dikeluarkan untuk kebutuhan primer makin kecil, sedangkan bagian untuk kebutuhan lain-lain semakin besar. Besar kecilnya pendapatan dan pengaruhnya terhadap jumlah barang dan jasa yang dikonsumsi dapat digambarkan dalam suatu kurva Engel. Kurva Engel adalah sebuah garis yang menunjukkan hubungan antara berbagai jumlah 
barang dan jasa yang akan dibeli pada berbagai tingkat pendapatan yang dimiliki ceteris paribus.

Berdasarkan tujuan penelitian, teori, dan konsep yang terlah diuraikan, maka dapat dirumuskan hipotesis; H1 : Program BPNT berpengaruh positif dan signifikan terhadap Konsumsi Rumah Tangga Penerima BPNT di Kecamatan Mengwi Kabupaten Badung; H2 : Program BPNT dan Konsumsi Rumah Tangga berpengaruh negatif dan signifikan terhadap Pola Konsumsi Rumah Tangga Penerima BPNT di Kecamatan Mengwi Kabupaten Badung ; H3 : Program BPNT secara tidak langsung berpengaruh terhadap Pola Konsumsi Rumah Tangga melalui Konsumsi Rumah Tangga Penerima BPNT di Kecamatan Mengwi Kabupaten Badung

\section{METODE PENELITIAN}

Desain penelitian ini menggunakan metode kuantitatif yang berbentuk asosiatif. Penelitian ini dilakukan di Kecamatan Mengwi Kabupaten Badung Bali dimana pada lokasi tersebut ada 5 kelurahan dan 15 desa, yakni Abian Base, Baha, Buduk, Cemagi, Gulingan, Kapal, Kekeran, Kuwum, Lukluk, Mengwi, Mengwitani, Munggu, Penarungan, Pererenan, Sading, Sembung, Sempidi, Sobangan, Tumbak Bayuh, Werdi Bhuwana karena di desa tersebut masih banyak terdapat masyarakat miskin untuk diberikan BPNT. Adapun objek penelitian adalah penyaluran BPNT yang diberikan oleh pemerintah kepada masyarakat miskin dengan kondisi sosial ekonomi 25\% terendah di daerah pelaksanaan, dengan variabel yang digunakan yaitu pola konsumsi rumah tangga (sebagai variabel terikat), program BNPT (sebagai variabel bebas), dan konsumsi rumah tangga (sebagai variabel mediasi). Populasi penelitian berjumlah terdapat 2523 keluarga yang menerima BPNT yang diberikan pemerintah setiap bulan pada tahun 2020, dengan sampel sebanyak 96 respon yang akan diberikan masing-masing memberikan 2 data yaitu sebelum dan sesudah menerima BNPT sehingga penelitian ini memiliki 192 data. Penelitian ini menggunakan data kuantitatif dan kualitatif berupa data BPNT, data konsumsi rumah tangga, data pola konsumsi rumah tangga. Data penelitian diperoleh melalui wawancara dengan keluarga miskin yang menerima BNPT (data primer), dan diperoleh dari pihak lain berupa data jumlah KPM tahun 2018 sampai 2020 dari Dinas Sosial Kabupaten Badung (data sekunder). Metode pengumpulan data yang digunakan adalah dengan menyebarkan kuesioner kepada responden sehingga diperoleh informasi yang relevan dan memperoleh informasi seakurat mungkin. Data penelitian akan dianalisis dengan menggunakan teknik analisis jalur.

\section{HASIL DAN PEMBAHASAN}

Berdasarkan penerima program BNPT, bantuan yang berupa bahan pangan senilai Rp 200.000 perbulan ini diharapkan mampu untuk membantu KPM dalam memenuhi konsumsi dan mengurangi pengeluaran keluarga penerima BPNT tersebut. Program BPNT ini adalah variabel dummy nilainya $=$ 1 sesudah menerima BPNT dan nilainya $=0$ sebelum menerima BPNT.

Berdasarkan konsumsi rumah tangga, nilai minimum konsumsi rumah tangga sebelum menerima BPNT sebesar Rp300.000 sedangkan sesudah menerima BPNT sebesar Rp500.000, nilai maksimum konsumsi rumah tangga sebelum menerima BPNT sebesar Rp2.500.000 sedangkan sesudah menerima BPNT sebesar Rp3.020.000, nilai rata-rata konsumsi rumah tangga sebelum menerima BPNT sebesar Rp1.187.739 sedangkan sesudah menerima BPNT sebesar Rp1.503.854, dan standar deviasi konsumsi rumah tangga sebelum menerima BPNT sebesar Rp577,199 sedangkan sesudah menerima BPNT sebesar Rp622,570. Data tersebut menunjukkan bahwa tingkat konsumsi sebelum menerima BPNT lebih rendah dibandingkan sesudah mendapatkan BPNT. Konsumsi

Dampak BPNT Terhadap Konsumsi Rumah Tangga Dan Pola Konsumsi Rumah Tangga Penerima BPNT, 
sebelum lebih rendah dari sesudah menerima BPNT artinya program BPNT mampu membantu meningkatkan konsumsi KPM.

Berdasarkan pola konsumsi rumah tangga, nilai minimum pola konsumsi sebelum menerima BPNT sebesar 24\% sedangkan sesudah menerima BPNT sebesar 17\%, nilai maksimum pola konsumsi sebelum menerima BPNT sebesar 48\% sedangkan sesudah menerima BPNT sebesar 42\%, nilai ratarata pola konsumsi sebelum menerima BPNT sebesar 34,8\% sedangkan sesudah menerima BPNT sebesar 30,2\%, dan standar deviasi pola konsumsi sebelum menerima BPNT sebesar 4,46\% sedangkan sesudah menerima BPNT sebesar 4,56\%.

Tabel 2

Statistik Deskriptif

\begin{tabular}{llcccc}
\hline & N & Minimum & Maximum & Mean & Std. Deviation \\
\hline Program BPNT & 96 & .00 & .00 & .0000 & .00000 \\
Program BPNT Sesudah & 96 & 1.00 & 1.00 & 1.0000 & .00000 \\
Rata-Rata Pendapatan per bulan & 96 & 400000 & 3500000.00 & 1873437.5000 & 787098.37294 \\
Konsumsi RT sebelum & 96 & 300000 & 2500000.00 & 1187739.5833 & 577199.76009 \\
Konsumsi RT Sesudah & 96 & 500000 & 3020000.00 & 1503854.1667 & 622570.84956 \\
Pola Konsumsi RT sebelum & 96 & 24.00 & 48.00 & 34.8229 & 4.46977 \\
Pola Konsumsi RT Sesudah & 96 & 17.00 & 42.00 & 30.2188 & 4.56117 \\
Valid N (listwise) & 96 & & & & \\
\hline
\end{tabular}

Sumber: Data Penelitian, 2021

Pada Jalur I, diperoleh hasil nilai signifikansi sebesar 0,000 kurang dari 0,05 sehingga model penelitian pada jalur I sudah layak. Pada jalur II, diperoleh nilai signifikansi sebesar 0,000 kurang dari 0,05 sehingga model penelitian pada jalur II sudah layak. Dengan demikian, dapat disimpulkan bahwa variabel independen program BPNT dan konsumsi rumah tangga secara simultan mempengaruhi pola konsumsi rumah tangga.

Berdasarkan nilai koefisien determinasi total sebesar 0,269 mempunyai arti bahwa sebesar 26,9\% variasi pola konsumsi rumah tangga dipengaruhi oleh variasi program BPNT dan konsumsi rumah tangga, sedangkan sisanya sebesar $73,1 \%$ dijelaskan oleh faktor lain yang tidak dimasukkan ke dalam model.

Tabel 3

Pengaruh Langsung dan Pengaruh Tidak Langsung serta Pengaruh Total Variabel Penelitian

\begin{tabular}{cccc}
$\begin{array}{c}\text { Pengaruh } \\
\text { Variabel }\end{array}$ & $\begin{array}{c}\text { Pengaruh } \\
\text { Langsung }\end{array}$ & $\begin{array}{c}\text { Pengaruh Tidak Langsung Melalui Konsumsi rumah } \\
\text { tangga }(\text { Y1 })(b 1 \text { x b3) }\end{array}$ & Pengaruh Total \\
\hline $\mathrm{X} \rightarrow \mathrm{Y} 1$ & 0,266 & - & 0,266 \\
$\mathrm{X} \rightarrow \mathrm{Y} 2$ & $-0,029$ & $-0,120$ & $-0,149$ \\
$\mathrm{Y} 1 \rightarrow \mathrm{Y} 2$ & $-0,452$ & - & $-0,452$ \\
\hline
\end{tabular}

Sumber: Data Penelitian, 2021 
Berdasarkan Tabel 3, dapat dijelaskan pengaruh langsung, pengaruh tidak langsung dan pengaruh total sebagai berikut: Besarnya pengaruh variabel Program BPNT (X) terhadap pola konsumsi rumah tangga (Y2) dengan konsumsi rumah tangga (Y1) sebagai variabel mediasi, dapat dihitung dengan rumus berikut :

$$
\mathrm{X} \rightarrow \mathrm{Y} 1 \rightarrow \mathrm{Y} 2=\left(\mathrm{b}_{1}\right) \mathrm{x}\left(\mathrm{b}_{3}\right)=(0,266) \mathrm{x}(-0,452)=-0,120 \ldots \ldots \ldots \ldots \ldots \ldots . . .(1)
$$

Pengaruh tidak langsung variabel program BPNT terhadap pola konsumsi rumah tangga melalui konsumsi rumah tangga sebesar -0,120. Berdasarkan hasil perhitungan, diketahui bahwa pengaruh langsung program BPNT terhadap konsumsi rumah tangga adalah sebesar 0,266. Pengaruh langsung variabel program BPNT terhadap pola konsumsi rumah tangga sebesar -0,029. Pengaruh langsung variabel konsumsi rumah tangga terhadap pola konsumsi rumah tangga sebesar $-0,452$. Hal ini berarti bahwa variabel pola konsumsi rumah tangga lebih besar dipengaruhi oleh konsumsi rumah tangga dibandingkan program BPNT. Jadi pengaruh total variabel program BPNT terhadap pola konsumsi rumah tangga adalah sebesar $-0,149$.

Berdasarkan hasil analisis pengaruh program BPNT terhadap konsumsi rumah tangga diperoleh nilai standardized coefficient beta sebesar 0,266. Nilai Signifikansi $0,000<0,05$ mengindikasikan bahwa $\mathrm{H}_{0}$ ditolak. Hasil ini mempunyai arti bahwa program BPNT berpengaruh positif dan signifikan terhadap konsumsi rumah tangga. Yang mempunyai arti bahwa rata-rata konsumsi rumah tangga setelah menerima BPNT lebih tinggi dibandingkan dengan rata-rata konsumsi rumah tangga sebelum menerima BPNT.

Sejalan dengan penelitian yang dilakukan oleh Josephine Ruth (2012) yang menyatakan adanya pengaruh yang signifikan bantuan sosial dalam raskin terhadap konsumsi rumah tangga miskin. Bantuan sosial mencakup program Indonesia Pintar (PIP), Program Jaminan Kesehatan (JKNKIS), Program Keluarga Harapan (PKH), dan Rastra/BPNT. Bantuan sosial dapat mengurangi beban pengeluaran keluarga miskin, terutama dalam hal pangan, pendidikan dan kesehatan. Peningkatan kualitas pendidikan dan kesehatan akan memberikan kesempatan kepada masyarakat untuk memperbaiki dan meningkatkan kualitas kehidupan mereka. Bantuan yang diberikan juga mampu untuk menambahkan gizi kepada penerima bantuan tersebut dan mampu membantu pengeluaran konsumsi keluarga oleh keluarga penerima manfaat. Sehingga pendapatan yang didapatkan oleh keluarga penerima manfaat dapat dialokasikan bukan hanya untuk keperluan bahan pangan saja tetapi dapat dialokasikan untuk keperluan non pangan. Berdasarkan penelitian dari Eka Rastiyanto dkk (2020) mengatakan bahwa efek kausal dari dampak subsidi Raskin pada konsumsi gizi rumah tangga adalah positif dan signifikan, ini menegaskan kembali peran subsidi Raskin dalam meningkatkan konsumsi gizi rumah tangga dan dimungkinkan dapat mengurangi kekurangan gizi dan kerawanan pangan rumah tangga. Karena itu, program subsidi pangan beras atau paket pangan lainnya perlu dilanjutkan untuk meningkatkan kualitas konsumsi pangan dan gizi rumah tangga miskin dan rentan miskin.

Berdasarkan hasil pengujian pengaruh program BPNT terhadap pola konsumsi rumah tangga diperoleh nilai standardized coefficient beta sebesar - 0,029 dengan nilai signifikansi sebesar 0,663 (dibagi 2 untuk uji satu sisi) $=0,331>0,05$ mengindikasikan bahwa $\mathrm{H}_{0}$ diterima. Hasil ini mempunyai arti bahwa program BPNT tidak berpengaruh signifikan terhadap pola konsumsi rumah tangga. Yang mempunyai arti bahwa rata-rata persentase konsumsi pangan terhadap konsumsi total setelah menerima BPNT tidak berbeda dengan rata-rata persentase konsumsi pangan terhadap konsumsi total sebelum menerima BPNT. Program BPNT berpengaruh negatif tetapi tidak signifikan terhadap pola konsumsi karena bertambahnya jumlah pangan yang diterima oleh KPM yang menerima bantuan pangan berupa BPNT akan menyebabkan penurunan pola konsumsi pangan KPM. Sehingga KPM akan mengalihkan pendapatan yang tidak dikeluarkan untuk membeli bahan pangan akan digunakan 
untuk memenuhi kebutuhan non pangan. hal ini berarti bertambahnya jumlah beras raskin yang diterima rumah tangga maka pengeluaran untuk konsumsi pangan rumah tangga akan berkurang perbulannya. Terdapat hubungan yang negatif antara jumlah beras raskin yang diterima untuk konsumsi pangan rumah tangga di daerah penelitian. Dimana dengan bertambahnya jumlah beras raskin yang diterima maka pengeluaran untuk konsumsi rumah tangga menurun. Hal tersebut jelas terlihat sesuai dengan BPS (2004) yang mengatakan bahwa Program Raskin bertujuan untuk mengurangi beban pengeluaran dari rumah tangga sebagai bentuk dukungan dalam meningkatkan ketahanan pangan dengan memberikan perlindungan sosial beras murah. Maka sebagian rumah tangga dapat mengurangi pengeluaran pangan dalam beras.

Hasil penelitian ini sesuai dengan hasil penelitian dari Ruth Josephine Robina Sinaga, Satia Negara dan Mozart B Darus (2017) yang menyatakan bahwa Raskin merupakan program pemerintah dalam penyaluran beras bersubsidi kepada rumah tangga miskin. Di tingkat desa/kelurahan, penetapan penerima manfaat menggunakan mekanisme musdes yang dilaksanakan secara transparan dan partisipatif dengan melibatkan berbagai unsur masyarakat termasuk perwakilan RTM. Besaran jumlah beras raskin yang diberikan kepada rumah tangga miskin sangat mempengaruhi pengeluaran konsumsi pangan rumah tangga tersebut

Berdasarkan hasil analisis pengaruh konsumsi rumah tangga terhadap pola konsumsi rumah tangga diperoleh nilai standardized coefficient beta sebesar -0,452. Nilai Signifikansi $0,000<0,05$ mengindikasikan bahwa $\mathrm{H}_{0}$ ditolak. Hasil ini mempunyai arti bahwa konsumsi rumah tangga berpengaruh negatif terhadap pola konsumsi rumah tangga. Semakin tinggi konsumsi rumah tangga maka rata-rata persentase konsumsi pangan terhadap konsumsi total akan menurun. Konsumsi rumah tangga berpengaruh negatif terhadap pola konsumsi rumah tangga karena KPM yang memiliki konsumsi tinggi akan memiliki persentase pengeluaran konsumsi pangan yang lebih kecil. Sehingga semakin tinggi konsumsi KPM yang menerima bantuan pangan berupa BPNT maka persentase pengeluaran konsumsi pangannya semakin rendah. KPM tidak membelanjakan uangnya hanya untuk membeli bahan pangan, tetapi KPM akan mengurangi pengeluaran untuk bahan pangan dan akan membelanjakan uangnya untuk keperluan non pangan.

Hal ini sesuai dengan penelitian Widjajanti, dkk (1996) yang menunjukkan bahwa respon rumah tangga terhadap pengeluaran pangan dan non pangan akan berkebalikan dimana jika konsumsi pangan meningkat, maka konsumen akan menurunkan konsumsi non pangannya, begitu pula sebaliknya. Hal ini juga sesuai dengan penelitian Burhanuddin, dkk (2013) yang menunjukkan bahwa harga beras akan meningkatkan pengeluaran rumah tangga. Konsumsi pangan pokok berbeda antar rumah tangga tergantung dari tinggi rendahnya tingkat pendapatan. Semakin tinggi tingkat pendapatan rumah tangga maka orang tidak akan menambah kualitas pangan pokok yang dikonsumsinya karena adanya kenaikan pendapatan akan memberi peluang bagi masing-masing rumah tangga untuk meningkatkan kualitas pangan pokok yang dikonsumsi agar dapat meningkatkan gizi keluarga atau bahkan mungkin akan membeli makanan lain sebagai pengganti pangan pokok. Pola konsumsi pangan tidak terlepas dari faktor sosial ekonomi artinya bagi rumah tangga yang berpendapatan rendah pola konsumsi pangannya mengarah pada pangan pokok yang berbasis potensi lokal, dan variasi pangan kurang mendapat perhatian sehingga pemenuhan gizinya masih perlu dipertanyakan. Berbeda dengan rumah tangga yang berpendapatan tinggi mereka cenderung untuk mengkonsumsi pangan yang bervariasi dan meningkatkan kualitas pangannya dengan cara membeli bahan pangan yang nilai gizinya lebih tinggi.

Berdasarkan hasil pengujian diperoleh nilai $Z$ hitung sebesar $-3,684$ sehingga $\left|Z_{\text {hitung }}\right|=$ 3,684>1,96, maka $\mathrm{H}_{0}$ ditolak. Artinya konsumsi rumah tangga (Y1) merupakan variabel yang memediasi pengaruh program BPNT (X) terhadap pola konsumsi rumah tangga (Y2) atau dengan kata

Dampak BPNT Terhadap Konsumsi Rumah Tangga Dan Pola Konsumsi Rumah Tangga Penerima BPNT, 
lain program BPNT secara tidak langsung berpengaruh terhadap pola konsumsi rumah tangga melalui konsumsi rumah tangga.

Berdasarkan hasil penelitian yang telah dilakukan, terdapat implikasi yang dapat dihasilkan dengan adanya penelitian ini. Hasil dari penelitian ini didapatkan bahwa program BPNT berpengaruh positif dan signifikan terhadap konsumsi rumah tangga yang artinya bahwa rata-rata konsumsi rumah tangga setelah menerima BPNT lebih tinggi dibandingkan dengan rata-rata konsumsi rumah tangga sebelum menerima BPNT. Subsidi yang diberikan mampu meningkatkan pendapatan melalui bantuan subsidi yang diberikan sehingga pendapatan tidak hanya digunakan untuk mengkonsumsi bahan pangan saja dengan adanya peningkatan pendapatan melalui subsidi tersebut dapat mengubah pola konsumsi pangan rumah tangga (Khausal dan Muchomba 2015) yang dapat mengakibatkan peningkatan konsumsi rumah tangga. Sehingga program dari pemerintah yaitu BPNT ini dianggap mampu untuk memenuhi tingkat konsumsi rumah tangga di Kecamatan Mengwi Kabupaten Badung.

Berdasarkan hasil penelitian yang telah dilakukan terdapat implikasi yang dapat dihasilkan dengan adanya penelitian ini. Hasil dari penelitian ini didapatkan bahwa program BPNT berpengaruh negatif dan tidak signifikan terhadap pola konsumsi rumah tangga yang artinya bahwa rata-rata persentase konsumsi pangan terhadap konsumsi total setelah BPNT tidak berbeda dengan rata-rata persentase konsumsi pangan terhadap konsumsi total sebelum menerima BPNT. Dalam penelitian ini program BPNT yang diberikan pemerintah kepada KPM berupa bahan pangan yang mampu membantu pengeluaran konsumsi KPM. Tetapi semakin tinggi pengeluaran konsumsi yang dikeluarkan oleh KPM maka rata-rata persentase konsumsinya akan semakin rendah. Fajar dkk (2016) pengeluaran rumah tangga menjadi ukuran pendapatan, semakin besar pengeluaran untuk non pangan menandakan semakin sejahtera kehidupan rumah tangga tersebut. Pergeseran pola pengeluaran dari pangan ke non pangan terjadi karena elastisitas permintaan terhadap pangan pada umumnya rendah, sebaliknya permintaan terhadap non pangan pada umumnya tinggi. Adanya program BPNT yang membantu untuk menambah pengeluaran pangan KPM sehingga KPM mampu untuk mengkonsumsi non pangan untuk memenuhi kehidupannya.

Berdasarkan hasil penelitian yang telah dilakukan terdapat implikasi yang dapat dihasilkan dengan adanya penelitian ini. Hasil dari penelitian ini didapatkan bahwa konsumsi rumah tangga berpengaruh negatif dan signifikan terhadap pola konsumsi rumah tangga artinya bahwa semakin tinggi konsumsi rumah tangga KPM maka persentase rata-rata konsumsinya menurun. Hal ini sesuai dengan penelitian (Widjajanti, E.; Li, 1996) yang menunjukkan bahwa respon rumah tangga terhadap pengeluaran pangan dan non pangan akan berkebalikan dimana jika konsumsi pangan meningkat, maka konsumen akan menurunkan konsumsi non pangannya, begitu pula sebaliknya. Terdapat kecenderungan bahwa rumah tangga yang memiliki pendapatan yang relatif lebih tinggi memiliki share pengeluaran konsumsi non makanan lebih banyak dibandingkan dengan rumah tangga yang memiliki pendapatan yang rendah. Sebaliknya, rumah tangga dengan tingkat pendapatan yang rendah memilih lebih banyak mengalokasikan pendapatannya untuk mengkonsumsi makanan. Sehingga konsumsi rumah tangga KPM di Kecamatan Mengwi Kabupaten Badung mampu mengalokasikan pendapatannya untuk memenuhi konsumsi berupa bahan pangan dan non pangan. Le (2008) yang menemukan hasil bahwa semakin miskin rumah tangga maka elastisitas pendapatan terhadap komoditas daging/ikan akan semakin tinggi yang menandakan semakin bersifat mewah komoditas tersebut sedangkan elastisitas pendapatan terhadap komoditas padi-padian dan non padi-padian akan semakin menurun, daya beli rumahtangga miskin umumnya sangat rendah menyebabkan alternatif substitusi pangan yang dimiliki kurang beragam. Kondisi ini sejalan dengan hukum Bennet yang menyatakan bahwa rumah tangga dengan tingkat pendapatan rendah, konsumsi pangannya akan lebih memprioritaskan pada pangan yang bersifat padat energi yang berasal dari karbohidrat, namun sejalan dengan peningkatan pendapatan maka pola konsumsi pangannya akan semakin terdiversifikasi dan umumnya akan terjadi peningkatan konsumsi pangan terhadap komoditas yang bernilai gizi tinggi (Soekirman, 2000) dalam (Ariani dan Hermanto, 2012). 


\section{SIMPULAN DAN SARAN}

Berdasarkan hasil analisis dan pembahasan yang telah diuraikan sebelumnya, maka dapat ditarik simpulan bahwa program BPNT berpengaruh positif dan signifikan terhadap konsumsi rumah tangga penerima BPNT di Kecamatan Mengwi Kabupaten Badung. Program BPNT tidak berpengaruh signifikan terhadap pola konsumsi rumah tangga penerima BPNT di Kecamatan Mengwi Kabupaten Badung. Konsumsi rumah tangga berpengaruh negatif dan signifikan terhadap pola konsumsi rumah tangga penerima BPNT di Kecamatan Mengwi Kabupaten Badung. Konsumsi rumah tangga memediasi pengaruh Program BPNT terhadap Pola konsumsi rumah tangga penerima BPNT di Kecamatan Mengwi Kabupaten Badung.

Berdasarkan hasil penelitian dan simpulan, maka dapat diajukan saran kepada Pemerintah diharapkan mampu untuk meningkatkan pendapatan rumah tangga miskin dengan menambah jumlah lapangan pekerjaan, memperluas akses bagi kaum wanita untuk memperoleh kesempatan di bidang pendidikan, keterampilan, pekerjaan yang layak di sektor formal sehingga dapat membantu peningkatan pendapatan rumah tangga khususnya rumah tangga miskin. Melihat masih tingginya jumlah tanggungan rumah tangga miskin, sebaiknya pemerintah daerah mensosialisasikan program Keluarga Berencana (KB). Sehingga jumlah tanggungan yang ditanggung oleh KPM terbatasi dengan jumlah anggota keluarganya sehingga konsumsi rumah tangga optimal dengan pendapatan yang diterima pada pekerjaan masing-masing KPM. Pemerintah juga diharapkan mampu untuk menaikkan jumlah bantuan yang diberikan kepada KPM sehingga kebutuhan konsumsi rumah tangga yang dibutuhkan mencukupi dan mampu merubah pola konsumsi rumah tangga KPM. Dengan itu KMP dapat mengalokasikan pendapatan bukan hanya untuk mengkonsumsi bahan pangan saja tetapi juga dapat mengkonsumsi non pangan seperti, biaya pendidikan, pengeluaran listrik, air, dan lainnya.

\section{REFERENSI}

Akhtar, Rizwan, Hongman Liu and Amjad Ali. 2017. Influencing Factor of Poverty in Pakistan : Time Series Analysis. International Journal of Economics and Financial Issues 2017, 7 (2), 216

Amrullah, E. R., Hidayah, I., Rusyiana, A., \& Statistik, B. P. (2020). Dampak Program Raskin terhadap Konsumsi Gizi Rumah Tangga di Pulau Jawa.

Ariani, M., \& Hermanto. (2012). Dinamika Konsumsi Pangan, (18), 101-123.

Badan Pusat Statistik (2004), "Survey Sosial Ekonomi Nasional (SUSENAS) 2004", Badan Pusat Statistik, Jakarta.

Burhanuddin; Lisna, V.; Rifai, N. (2013). Analisis Ekonomi Makro yang Memengaruhi Tingkat Konsumsi Pangan dan Nonpangan Pada Masa Awal Reformasi. In Ekonomi dan Manajemen Ketahanan Pangan (pp. 119-136). IPB Press.

Choesni, T.A. 2017. Pedoman Pelaksanaan Bantuan Pangan Non Tunai. Kementrian Koordinator Bidang Pembangunan Manusia dan Kebudayaan, Jakarta.

Dumairy. 1996. Perekonomian Indonesia. Yogyakarta: Erlangga

Fajar, Endang, dan Sri Marwanti. 2016. Analisis Pola Konsumsi Rumah Tangga Petani Jagung Di Kabupaten Grobogan. Jurnal Ilmu Pertanian. Vol.28. No. 2. Hal 41-45

Kaushal, N., \& Muchomba, F. M. (2015). How consumer price subsidies affect nutrition. World Development, 74, 25-42.

Kementrian Sosial Republik Indonesia, Petunjuk Teknis Bantuan Pangan Non Tunai (Jakarta, 2017), 15-16.

Le, C. Q. (2008). An Empirical Study. JIEP-Vol. 18, No 1, Maret 2018 ISSN (P) 1412-2200 E-ISSN 2548-1851 49 of Food Demand in Vietnam. ASEAN Economic Bulletin, 25(3), 283-292.

Sinaga, R. J. R., Lubis, S. N., \& Darus, M. B. (2017). Kajian faktor-faktor sosial ekonomi masyarakat terhadap ketahanan pangan rumah tangga di Medan. Journal of Agriculture and Agribusiness Socioeconomics, 2(5), 15067.

Sukirno. 2001. Pengantar Makro Ekonomi : Edisi II. Jakarta: Grafindo Persada 
Vincent, Brian. 2009. The Concept'Poverty towards Understanding in The Context of Development. Vol. 2 No. (2). Journal of Sustainable Development

Widjajanti, E.; Li, E. (1996). Food Expenditure Pattern in Urban and Rural Indonesia: 1981 to 1993. Australian Agribusiness Review, 10(1), 93-111. 